\title{
Patient Experience with COVID-19 in Indonesia
}

\author{
Mohamad Judha $^{1 *}$, Elizabeth C. Baua ${ }^{2}$, Josephine D. Lorica ${ }^{2}$ \\ ${ }^{1}$ School of Nursing, Respati University Yogyakarta, Indonesia \\ ${ }^{2}$ School of Nursing and Allied Health Sciences, St. Paul University Philippines
}

\section{*Corresponding Author}

Mohamad Judha

\section{Article History}

Received: 09.03.2021

Accepted: 14.04 .2021

Published: 24.04.2021

\begin{abstract}
Background: Indonesia when it related disease Covid-19 tended to increase in number, in some home sick in Jakarta and several cities large in Indonesia, by a team of group assignment Indonesia, patient covid are at the age actively, and without symtoms. Mortality are high the world is in 5-9\% of patients led to fears of its own in the community. The necessity of insulating themselves become important leaving easy transmission of the patient to the healthy. The community is afraid and has a negative stigma that causes Covid 19 sufferers to be ostracized. Another thing that is not less important is the disruption of basic needs when suffering from illness. Aims: exploring the experience of participatory suffering from Covid-19. Methods: This study is a qualitative exploratory study to explore the experiences of Covid-19 participants. Participants study amounted to nine participants with a purposive sample. Results: The experience of participants gives an idea as a whole knows the feeling of the participants faced Covid-19 and change the value, trust and confidence of patients Covid-19. The results of the study $t$ erdapat response of the patient in the face of illness Covid-19 related to the activity of the physical, psychological and changes in the environment as well as changes in values, beliefs and convictions. Conclusion: In the study it was obtained nine themes among others: (1) feeling or response that is experienced in the face of illness Covid-19, (2) type of attention or support that is obtained from the environment to face Covid-19, (3) discrimination are experienced by participants Covid-19, (4) Efforts made by Covid-19 participants to achieve recovery , (5) Ability to recognize signs and symptoms of disease / physical changes, (6) Changes in values, beliefs and beliefs and expectations of Covid-19 sufferers. Recommendation: The results of the study suggest energy treatments do care that is comprehensive, for the power of education also should give how do care nursing holistic and provide education to the community about Covid-19.
\end{abstract}

Keywords: Patient Covid-19, the meaning of life of patients, Theory comfort.

\section{INTRODUCTION}

Covid-19 disease is a condition in which the immune system experiences a disorder that causes the body's cells to experience inflammation and damage. When the disease Covid-19 attack on myself someone then the body will produce antibodies in quantity which is sufficient, but if the body in the state is weak then it will appear the disease, the disease concomitant who are comorbid would worsen the state of the patient.

In patients with Covid-19 80\% of whom will get symptomatic therapy and drugs that increase endurance, in patients with low endurance and stress will then have an impact that neutrophil function (white blood cells) will change causing the ability to kill microbes decrease [1].

In Indonesia the disease Covid-19 tended to increase in number in some home sick in Jakarta, based on the data team group assignment Indonesia, patient Covid-19 manifold sex who suffer evenly between men and women. Most people with the status of the age of the active, and the many without any symptoms of the disease [2].

Some of the problems are caused by diseases Covid-19 will take effect in several diseases such as hypertension, cardiac, diabetes mellitus and even disorder failed kidneys are progressive, which eventually can lead to death of or change in physical others will affect the condition of the physical and psychological. So that it can weaken mental conditions which will further reduce the quality of life [3].

Copyright (C) 2021 The Author(s): This is an open-access article distributed under the terms of the Creative Commons Attribution 4.0 International License (CC BY-NC 4.0) which permits unrestricted use, distribution, and reproduction in any medium for non-commercial use provided the original author and source are credited. 
As a result of the changes that arise and because the process of healing the old as well as the disruption of the needs of basic Maslow, as well as the stigma negatively in society can lead to sadness were prolonged for the sufferer. Sadness that is prolonged is called grief chronic [4]. From the results of research (Indonesian Covid-19 task force team, 2020) in Indonesia, especially Jakarta, the number of sufferers who do not know the term Covid-19 is 56.4\%, a risk that can increase Covid-19 disease in general, many do not know until 79.2\%, and how to behave, in daily life on a regular basis only $19.3 \%$ (Indonesian Covid-19 task force team, 2020).

According to Udell JA, Zawi R, Bhatt DL et al., [5] and Huang C, Wang Y, Li X et al., [6], respiratory diseases including Covid-19 cause various damage to organ systems such as heart disease and other diseases that require long treatment so that sometimes cause psychological responses and need support. It is supported by [7] and the, National Health Commission of the People's Republic of China, 2020 [8], which says patients Covid-19 requires the support of the people around the patient in order to keep survive with the disease. Support which takes the form of support for social, support financially, support mental derived from family, labor health, the community around and governments.

\section{METHOD}

This research design uses a phenomenological approach. In this qualitative descriptive research design, there are three steps in the process of descriptive phenomenology, namely intuition, analysis and description. At the stage of intuition of researchers trying to unite as a whole phenomenon that is experienced by the patient, analysis is done by grouping the theme that exist on the experiences of participants Covid-19. Step further, the researchers tried to do the analysis to look for linkages between the phenomena that exist. Researchers tried to describe the use of English write about anything that happens in patients Covid-19 to focus questions on issues of physical, psychological, social and spiritual, researchers use a technique snowball, saturation is achieved until the saturation of the data obtained.

\section{RESEARCH RESULTS}

In research it obtained nine participants, all women are in the range of age were productive. All participants lived in Indonesia in the area, Jakarta, Yogyakarta, Semarang, and Surabaya.

\begin{tabular}{|l|l|l|l|l|l|l|}
\hline Participants & Age & type gender & Education & Status & Profession & City \\
\hline 1 & 35 & Male & Junior High School & Married & Employees & Jakarta \\
\hline 2 & 40 & Male & Junior High School & Married & Employees & Jakarta \\
\hline 3 & 28 & Male & High school & Married & Employees & Semarang \\
\hline 4 & 17 & Male & High school & Not Married & Student & Jogjakarta \\
\hline 5 & 27 & Male & High school & Married & Traders & Surabaya \\
\hline 6 & 36 & Woman & Bachelor & Married & Nurse & Yogyakarta \\
\hline 7 & 20 & Woman & Bachelor & Not Married & College student & Yogyakarta \\
\hline 8 & 25 & Woman & Bachelor & Married & Employee / Trader & Surabaya \\
\hline 9 & 37 & Woman & Masters & Married & Teacher & Jakarta \\
\hline
\end{tabular}

In research it obtained nine themes among others: (1) feeling or response that is experienced in the face of illness Covid-19, (2) type of attention or support that is obtained from the environment to face Covid-19, (3) discrimination are experienced by participants Covid- 19, (4) Efforts made by Covid-19 participants to achieve recovery, (5) Ability to recognize signs and symptoms of illness / physical changes, (6) Changes in values, beliefs and beliefs and expectations of Covid-19 sufferers.

\section{Discussion of Research Results}

Suffer Covid-19 for a person will cause disruption of comfort, not only in physical but also in psychological, comfort is the experience that is received by a person of an intervention. It is an experience immediate and thorough when it needs physical, psychospiritual, social, and environment are met [9]. The concept of the theory of comfort covering the needs of comfort, the intervention of comfort, a variable intervention, increase comfort, behavior seekers health and integrity of the institutional. According Kolcaba [10] things that can be described within the framework of conceptual as follows: 


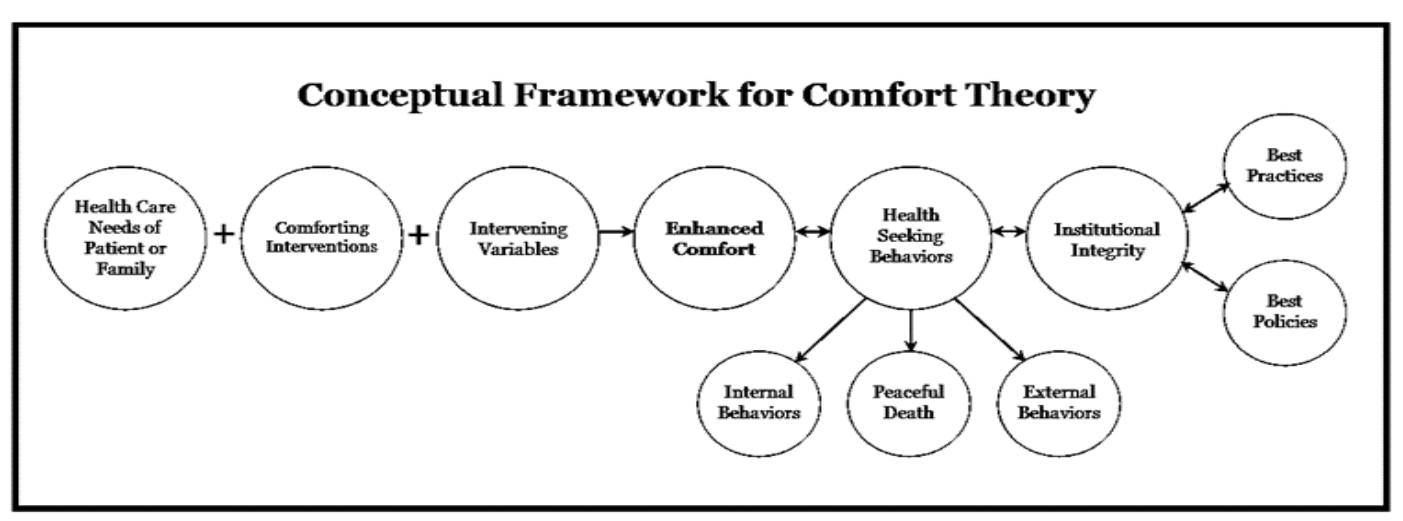

Fig-1: Framework Working Conceptual on Theory of Leisure

The whole concept of it associated with the client and family. Theory comfort consisting on three types, namely (1) relief: the condition of the recipient that require handling specific and immediate, (2) ease: the condition of serene or satisfaction hearts of clients that occur due to the loss of discomfort physical that is felt on all the needs, (3) transcendence: a situation where an individual is able to overcome the problem of the discomfort that occurs.

According to Kolcaba, K and Marguerite A. DiMarco [10] comfort is the basic need of an individual that is holistic, including physical, psychospiritual, sociocultural, environmental comfort. Physical comfort is related to the sensation mechanism of the body and homeostasis, including a decrease in the body's ability to respond to a disease or invasive procedure.

Some alternatives to meet physical needs are giving medication, changing positions, backrub, warm or cold compresses, therapeutic touch. Leisure psychospiritual associated with the harmony of heart and tranquility of the soul, which can be facilitated by facilitating the needs of interaction and socialization client with people nearby during treatment and involve the family are active in the process of healing the client [11].

\section{Feeling or response that is experienced in the face of illness Covid-19}

Results of the study found a variety of reactions about the fact that in the feeling when the first time to get the information that he was suffering from disease Covid-19, there are five categories of response that is felt participants, namely the feeling deny, m direction, bargaining / haggling over what the experienced, depression and receive above what the te $r$ so on self participants.

According Bratawijaya, Karnen, G [12], the age of influential big on emotion, functioning social, health mental, physical and health in general of patients Covid-19. In the study of this, the category of age of the participants were in the range of 17 to 40 years, things this means that all the participants in the study is located on a range of ages productive so that will impact on the response related to social, economic, biological, psychological and spiritual participants in the face of Covid-19 and also related to how the meaning and expectations of the events that occurred.

It is in accordance with the results of the research of Judha [13], which states that the age be part of an important person in the face of problems by as experience personally that obtained in addition of the education and the environment. Quoted from the Daily Kompas [14] there is a relationship which is close to the coping and response suffers Covid-19 when someone has the education, type of work, as well as the social economy, including also insurance for the health of the possessed. The more high- level the response and kopingnya also getting better. The results of the study have demonstrated that age determines how the participants in the reply shows characteristics that differ in levels of age are different as well.

\section{The type of attention / support you get to deal with Covid-19}

In participants study this, people around the participants showed interest in that great against the problem of disease Covid-19 who suffered participants. There are a variety of attention that is obtained, among others from the parents, from friends and family.

The existence of concern from the environment related to Maslow's hierarchical concept means providing a sense of security and comfort related to respect and feeling loved by the environment around the participants. The function of the support that is done by people around the participants will influence the feelings positively be higher with a way to validate the belief that there, pushing to provide information and advice as well as support material. 
Participants who get the support of the environment on the concept of being, belonging and becoming will show desire needs what are needed, what that had to do and how to preserve something that has been achieved in the face of Covid-19.

One of the nursing figures who developed theoretical concepts at the middle range theory level was Katharine Kolcaba with the theory of comfort. Kolcaba considers the application of comfort theory to be universal and can be applied to meet client needs in a holistic manner (biologically, psychologically, socially and spiritually).

Under the terms of that, nurses need to understand the relationship between philosophy, a paradigm with a theory of nursing were developed by Kolcaba with the purpose able to apply the theory that in the scope of practice and research to improve the quality of life client by any one needs essentially, namely comfort.

\section{Discrimination are experienced by participants Covid-19}

Some participants felt the stigma in society, even one participant felt discrimination from health workers in providing services, on the other hand discrimination there were participants who felt the delamination that said that Covid-19 patients will not recover, Covid-19 is a dangerous disease and by suffering from Covid-19 disease means that the death of Covid-19 patients is near death.

The existence of discrimination and stigma experienced causes the participant's psychological disruption and is felt as an discomfort in the participants' feelings, so if this does not get good intervention support it will cause new stressors for participants. The stigma in society causes insecurity and discomfort for participants, if this continues, participants feel not free to express feelings and as a result, learning processes and completing their curiosity about Covid-19 disease to achieve recovery are hampered.

Needs comfort sociocultural associated with relationships interpersonal, family and society, covering the needs of the information discharge (discharge planning), and treatments that correspond to the culture of the client. Some ways to meet the needs of sociocultural is creating relationships therapeutic with clients, respect the rights of clients without looking at the status of social or cultural, encourage clients to express their feelings, and facilitate team work which address the possibility of any conflict between the process of healing the culture of the client. Needs of the latter is the need to be the comfort of the environment that is associated with maintaining the neatness and cleanliness of the environment, limiting visitors and therapy when clients rest, and provide the environment that is safe for the client [15].

\section{Efforts made by sufferers of Covid-19 to recover}

The results stated that participants tended to keep their distance when interacting socially, using personal protective equipment with masks as well as in all their activities often washed their hands. Family members are also involved and always attached to each other in an effort to prevent Covid-19 infection.

At the study 's various ways taken so that the participants can be cured or protected from relapse Covid-19. It is berkaitandengan intent and purpose the participants perform various efforts to achieve cure the activities were carried out based on the awareness to be healthy by way of manipulating the self and the environment around through the insulation self.

According to the Kompas [14], Efforts to health is every activity and / or a series of activities were carried out in an integrated, Integrate and continuous to maintain and improve the degree of health of the community in the form of prevention of disease, improvement of health, treatment of diseases and restoration of health by governments and / or the community.

According to Judha and Deden [4], it was obtained that education plays an important role in improving a healthy lifestyle against diseases suffered, this means that with a high level of education leads to a chance of healthy living desires and avoided the same disease becomes higher.

\section{Changes in values, beliefs and beliefs and expectations of people with Covid-19.}

Some participants said that what happened to him was natural because of his insancy, others said that what happened made him more surrendered to God.

According to the concept of nursing, spiritual meaning still has something to do with words such as hope, meaning, harmony, and belief system [4]. Nurses find that spiritual aspect in one's relationship with one's own, as well as others and with God. According to March, A. \& McCormack, D [16] spiritually includes interpersonal intrapersonal (relationship between one's self) interpersonal (relationship between others and the environment), as well as transpersonal (i.e. an intractable relationship with the godhead which is the highest strength). According to Roos, Susan 
[17], Spiritual is defined as the essence of man entering and also affecting his life and manifested in the form of thought and behavior as well as in relation to himself, and others, nature, as well as with God.

\section{The concept of Spiritual in Nursing}

According to Tomey, AM and Alligood [18], The nurse looked at the client as being biopsiko sociocultural and spiritual respond is unique to changes in health or the condition or state of crisis. The nurse tried to help facilitate in case it meets the needs of spiritual client that is part of needs thorough client, among others to facilitate the fulfillment of the needs spiritual client that, although the nurse and the client has the confidence of spiritual or religious are different.

\section{SugGeSTIONS}

Participants in this study were all Indonesian citizens, in eastern culture, especially Indonesia, there is still shame or taboo to reveal something that is sensitive in nature, for example issues of sexuality and reproduction. Because of these constraints, there are probably many themes that have not been explored in depth. The gender difference between participants and researchers may be an obstacle in disclosing specific or sensitive matters. Participants may be reluctant to express many rights given these "uncomfortable" feelings.

To improve the quality of optimal nursing services, it is necessary to conduct training in the assessment of Covid-19 patients at the polyclinic and in the treatment room in the form of an assessment spreadsheet that can be understood easily and not only focuses on physical assessment but also psychological assessment, and requires collaboration with nurses from other departments, for example the community for follow-up care for Covid-19 care in the community.

\section{REFERENCES}

1. Sood, N., Simon, P., Ebner, P., Eichner, D., Reynolds, J., Bendavid, E., \& Bhattacharya, J. (2020). Seroprevalence of SARS-CoV-2-specific antibodies among adults in Los Angeles County, California, on April 10-11, 2020. Jama, 323(23), 2425-2427.

2. Team Force task Civid-19 Indonesia. (2021). Data accumulation trend is nationwide from 2020 to 2021 , Indonesia. https://covid19.go.id/peta-sebaran-covid19

3. Yang, X., Yu, Y., Xu, J., Shu, H., Liu, H., Wu, Y., ... \& Shang, Y. (2020). Clinical course and outcomes of critically ill patients with SARS-CoV-2 pneumonia in Wuhan, China: a single-centered, retrospective, observational study. The Lancet Respiratory Medicine, 8(5), 475-481.

4. Judha, M., \& Deden, I. S. (2015). What and How is Lupus Disease? Gosyen Publising, Yogyakarta. Indonesia.

5. Udell, J. A., Zawi, R., Bhatt, D. L., Keshtkar-Jahromi, M., Gaughran, F., Phrommintikul, A., ... \& Cannon, C. P. (2013). Association between influenza vaccination and cardiovascular outcomes in high-risk patients: a metaanalysis. Jama, 310(16), 1711-1720.

6. Huang, C., Wang, Y., Li, X., Ren, L., Zhao, J., Hu, Y., ... \& Cao, B. (2020). Clinical features of patients infected with 2019 novel coronavirus in Wuhan, China. The lancet, 395(10223), 497-506.

7. Corrales-Medina, V. F., Musher, D. M., Wells, G. A., Chirinos, J. A., Chen, L., \& Fine, M. J. (2012). Cardiac complications in patients with community-acquired pneumonia: incidence, timing, risk factors, and association with short-term mortality. Circulation, 125(6), 773-781.

8. National Health Commission of the People's Republic of China. Chinese management guideline for COVID-19 (version 6.0). Feb 19, 2020.

http://www.nhc.gov.cn/yzygj/s7653p/202002/8334a8326dd94d329df351d7da8aefc2/files/b218cfeb1bc54639af227f9 22bf6b817. pdf (accessed Feb 19, 2020; in Chinese).

9. Peterson, S. J., \& Bredow, T. S (2008). Middle Range Theories: Application to Nursing Research. $2^{\text {nd }}$ ed. Philadelphia: Lippincott Williams \& Wilkins.

10. Kolcaba, K., \& Marguerite A. DiMarco (2005). Comfort Theory and Its Application to Pediatric Nursing. Retrieved from: http://medscape.com/viewarticle/507387_2

11. Krinsky, R., Murillo, I., \& Johnson, J. (2014). A Practical Application of Katherine Kolcaba's to Cardiac Patients. Retrieved from: http://www.researchgate.net/publication/260216101

12. Bratawijaya-Karnen, G. (2002). Basic immunology (fifth edition). Jakarta, UI.

13. Judha, M. (2019). Family Perception in Readiness Accepting Discharge Planning Determined by Nursing Advocacy Program. Inject Journal. Jakarta, Indonesia. http://dx.doi.org/10.24990/injec.v4i2.268

14. Kompas. (2020). Covid-19 Pandemic Stress Cause Family Burnout, Here's the Good ... downloaded on 20/12/2020 at https://health.kompas.com/read/2020/07/10/193300868/stres-pandemi -covid-19-causes-family-burnout-like-thisgood - ? page $=$ all .

15. Kolcaba, K., Tilton, C., \& Drouin, C. (2006). Comfort theory a unifying framework to enhance the practice environment. The Journal of Nursing Administration, 36(11), 538-544. Retrieved from: http://thecomfortline.com/files/pdfs/2006. 
16. March, A., \& McCormack, D. (2009). Nursing Theory-Directed Healthcare Modifying Kolcaba's Comfort Theory as an Institution-Wide Approach. Holistic Nursing Practice. Retrieved from: http://www.ncbi.nlm.nih.gov/pubmed/19258847

17. Roos, S. (2002). The series in death, dying, \& berevement, Chronic sorrow a living loss. New York. BrunnerRoutledge.

18. Tomey, A. M., \& Alligood. (2010). Nursing Theorist and Their Work (7th ed). St. Louis: Mosby Elsevier.

CITATION: Mohamad Judha et al (2021). Patient Experience with COVID-19 in Indonesia. South Asian Res J Nurs Health Care, 3(2): 27-32. 